\title{
Future of smallholders in the dairy sector: A macro study of Gujarat
}

\author{
Shiv Raj Singh ${ }^{1}$, Thakar KP ${ }^{1}$, Soumya $C^{1}$ and KK Datta ${ }^{2}$
}

Received: 08 May 2019 / Accepted: 23 July 2019 / Published online: 28 October 2019

(c) Indian Dairy Association (India) 2019

\begin{abstract}
A study was conducted to examine the structural changes in dairy production front, inclusiveness of dairy farming in livelihood structure of farmers and to conceptualize the structural changes in organized dairy processing industry in Gujarat state. Overall milk production in Gujarat is increased by the combined effect of population (59.62\%) and yield effects $(39.14 \%)$. The income from dairy farming increased higher $(1.40$ times over the decade) as compared to other income activities (crop production, off-farm business, wages and salaries) and has an equalising effect on the distribution of farm income. Contribution of dairy income in farm income is higher especially in the case of marginal (37.97\%) and small (31.01\%) land owning farm households. At the same time, income of dairy farmers is higher compared to non-dairy farmers. Ex-factory value of output per organized dairy processing factory increased 4.20 times while, fixed capital investment increased 18.45 times over the period (2000-01 to 2015-16). This indicates that the excess investment in dairy industry might have happened over the period which has not perhaps resulted in increase in value of output from the industry. This trend shows that it is possible that without addition in capital investment, organized dairy industry can sustain in near future the condition is to use full capacity, this way dairy
\end{abstract}

1Department of Agricultural Economics, C.P. College of Agriculture, S.D. Agricultural University, Sardarkrushinagar, Gujarat- 385 506, India

2Central Agricultural University, School of Post Graduate Studies, Umroi Road, Umiam, Meghalaya - 793 103, India

Shiv Raj Singh $(\varangle)$

Department of Agricultural Economics, C.P. College of Agriculture, S.D. Agricultural University, Sardarkrushinagar, Gujarat- 385 506, India E-mail: shivagritech2007@gmail.com; Phone:+91-9427138530 industry and farmers remain in win-win situation. The government should give more focus on promotion of dairy farming in the programmes designated for enhancing farmer's income and in reducing income inequalities.

Keywords: Dairy, Gujarat, Inclusiveness, Organized dairy industry

\section{Introduction}

Dairying is an important activity in Indian economy contributing about 27 per cent of the agricultural gross domestic product (AgGDP) and which around 4.00 per cent of the national GDP (CSO 2016-17). Similarly in Gujarat state economy, share of livestock sector is about 20 per cent of agriculture gross state value addition (GSVA) and it is 3.14 per cent of state GSVA. Whereas, milk sector contribution is around 21 per cent of total value of agriculture output of Gujarat state. Over the last fifteen years (2000-01 to 2015-16) milk production of state has increased around 2.31 times whereas value of milk output increased around 8 times at nominal price level (NDDB \& CSO-2008/2018). This trend shows the increasing importance of dairy sector in Gujarat economy.

Dairying in India is more inclusive compared to crop production in the sense that it involves a majority of the vulnerable segments of the society for livelihoods. Livestock population is more equitably distributed than the land (Kumar and Singh, 2008). The income from livestock sector helps in alleviating poverty and smoothening of income distribution. A recent study indicated that the benefits of growth in agriculture have trickled down to the rural poor and the distributive growth has been inclusive (Kumar et al. 2011). Nearly two-thirds of farm households in India are associated with livestock production, and 80 per cent of them are small landholders ( $\leq 2 \mathrm{ha}$ ). The livestock, specifically dairying is a supplementary enterprise to crop farming and is highly integrated with crop production. Smallholding households' dependence on the crop sector reduced over the years while, off-farm and dairying income share have increased. The income from off-farm and dairy farming also reduces the income equality across the different categories (Singh and Datta, 2013; Mandal et al. 2010). The dominance of smallholding farmers' role in milk 
production has increased in most Indian states between 2003 and 2013 (Kumar et al. 2018). The income from dairy farming varies widely across the different farm categories. The proportion of household income from livestock and dairying to total family income of the households is also inversely related to land ownership. Across the landholding categories income of livestock keeping households and non-livestock keeping households varies from 24 to 75 per cent where contribution of dairy farming income is about 16 to 49 per cent across the landholding categories (Singh and Datta, 2013).

More than 75 per cent of the farmers keep 2-3 milch animals for subsistence of their livelihoods. The structure of milk production is largely based on low input and low-to-moderate output which fits into the resource endowments of small producers in terms of ownership of land, family endowment as also with common property resources. The farmers' perception about input use and its outcome is usually traditional. However, in Gujarat, certain segments of rural population have taken up dairying progressively as a means of full employment. The traditional farms of dairy enterprises have given way to commercial farms with escalation in average production, bringing in modernity in farm practices and use of dairy farm power and mechanization.

Milk processing in India is around 35 per cent of total milk production, of which the organized dairy industry account for only 13 per cent of the milk produced, the remaining 22 per cent is processed in the unorganized sector. The organized dairy sector uses 80 per cent of the liquid milk for pasteurization and the rest for butter, cheese, and milk powder. The organized dairy sector has registered capacity to process around 65 per cent of the country's rural marketable surplus and about one-third of national milk production. In the post-liberalization era, organized dairy sector could continue its momentum as has been reflected through the growth pattern $(5.12 \%)$ of dairy units, whereas the value of output during this period increased at the rate of 12.43 per cent, reflecting convergence of small units into larger units ensuring economies of scale. During post-liberalization era, milk production increased at the rate of 3.64 per cent per annum but value addition increased much faster, at the rate of 4.34 per cent per annum (Singh and Datta, 2010).

This paper attempts to examine the structural changes in dairy production front, inclusiveness of dairy farming in livelihood structure of farmers and to conceptualize the structural changes in organized dairy processing industry.

\section{Materials and Methods}

\section{Description of data sources}

The study was based on the secondary data, available from National Sample Survey Organization (NSSO) unit level data on Situation Assessment Survey of Farmers-2003, Situation
Assessment Survey of Agricultural Households-2012-13 along with various Integrated Sample Survey reports (2000-01 to 201718) and milk production statistics from Department of Animal Husbandry, Dairying and Fisheries. To study the organized dairy industry structural changes and technological changes, Annual Survey of Industries unit level data was used for the period of 2000-01 to 2015-16.

\section{Analytical tools}

Data on population distribution pattern and milk production of different bovine species across the districts and regions, structural changes and income dynamics across the landholding categories of households was analysed through tabular analysis and percentage method. Decomposition analysis was carried out to assess the relative contribution of population and yield to the growth of milk production (Kumar et al. 2013).

$$
\Delta Q=\Delta P . Y^{0}+\Delta Y . P^{0}+\Delta P . \Delta Y
$$

Where,

$$
\begin{aligned}
& \Delta Q=Q_{t}-Q_{0} \\
& \Delta P=P_{t}-P_{0} \\
& \Delta Y=Y_{t}-Y_{0}
\end{aligned}
$$

Here, $\Delta P . Y^{0}$ represents the population effect, $\Delta Y . P^{0}$ represents the yield effect, and $\Delta P . \Delta Y$ represents the interaction effect. $Q, Y$ and $P$ represent milk production, milk yield and population, respectively; subscripts $o$ and $t$ represents the base year and terminal year, respectively.

To study the inclusiveness of dairy farming in livelihood structure of farmers', source wise decomposition of Gini index (Singh and Datta, 2013) technique was applied. A key rationale for studying decompositions by source is to estimate how the changes in particular income source will affect overall income inequality.

To study the structural changes in organized dairy industry tabular analysis along with Total Factor Productivity (TFP) method was used. For estimating purpose of TFP growth, this study was used Malmquist Index approach (Ghose and Biswas, 2012). The brief definition of variables used for estimating Total Factor Productivity (TFP) change is given as:

\section{Output}

Ex-factory value of output of main product and by-product during the accounting year. 


\section{Capital}

User's cost of capital, i.e., a sum of depreciation, interest payment and rent is used to estimate the capital use in dairy industry.

\section{Labour}

The Annual Survey of Industry provides two categories of labour employment in dairy industry, i.e., employees and workers. The data available on number of employees employed in dairy industry is used in the study.

\section{Raw Material}

Raw material is the major input used in dairy industry basically constituting raw milk, dairy inputs, chemicals, water, non-basic chemicals, imported material/items, ice and packing materials etc.

\section{Energy}

Values/costs of different types of energy, mainly includes electricity diesel, petrol and coal, oil, lubricants consumed and other fuel consumed used in dairy industry.

The data on value of output and inputs of dairy industry units is converted into constant prices considering 1993-94 as the base year by using appropriate price index of respective commodity groups and inputs.

\section{Results and Discussion}

\section{Population distribution and milk production of different bovine species in Gujarat}

Table 1 shows the growth rate of population and milk production of different bovine species across the different districts and regions of Gujarat. In North Gujarat region, all bovine species population has increased over the study period, whereas South Gujarat region witnessed a decrease in population of indigenous cows over the same period. North Gujarat region recorded a high increase in growth of milk production in crossbred cows, i. e. 17.42 per cent which is higher than Gujarat state as a whole $(16.50 \%)$. This is due to Banaskantha (25.02\%) and Sabarkantha (18.66\%) districts region recording a higher growth in milk production of crossbred cows. Saurashtra regions of Gujarat recorded higher increase in the growth of population of crossbred cows, indigenous cows and buffalo. In the case of indigenous cows, the growth in milk production was higher in Saurashtra and Central Gujarat regions than that of Gujarat state as a whole. In Saurashtra region, all districts except Porbandar and Rajkot, recorded a higher growth in milk production of indigenous cows than that of whole state and in Central Gujarat region, Panchmahal and Dahod showed the same trend. In the case of buffalo, the growth in milk production was higher than state as a whole in Saurashtra and Central Gujarat regions, i. e. 4.84 and 4.25 per cent. In Saurashtra region, except Bhavnagar and Porbandar, all districts showed a higher growth in milk production than that of state as a whole while, in Central Gujarat region, all districts except Anand, Dahod and Vadodara showed the same trend. Only North Gujarat region showed a higher growth in milk production, i. e. 6.25 per cent in the case of bovine than Gujarat as a whole (5.69\%). This is due to the higher increase in growth of milk production in crossbred cows in this region. In Gujarat state, highest increase in growth of milk production was observed in the case of crossbred cows, i. e. 16.50 per cent as compared to other bovines. Same trend was observed in all the regions of Gujarat. Nearly 4.09 per cent increase in growth of milk production was observed in buffalo in Gujarat state as a whole. Trend is also similar for other regions of Gujarat except South Gujarat. In South Gujarat, the lowest growth in milk production was observed in indigenous cows mainly attributed to the decrease in growth in milk production in Navsari (-4.41\%) and Surat (-3.19\%) districts.

\section{Sources of growth in milk production}

The results of decomposition of yield and population effects of livestock to growth of milk production during the period 2000-01 to 2017-18 is presented in Table 2. In the case of crossbred cow, the increase in milk production is mainly attributed to the population effect $(92.05 \%)$ than the yield effect $(7.28 \%)$ over the study period. Increase in local cow milk production is the resultant of combined effect of population (54.80\%) and yield effect $(44.67 \%)$. While in the case of buffalo, the increase in milk production was mainly lead by population effect $(63.05 \%)$ and yield effect (35.99\%) complementing it. In the connotation of this trend, milk production of bovine in state is increased by the combined effect of population (59.62\%) and yield effects (39.14\%). These results highlight the importance of yield led technological intervention to enhance the milk production of local cows and buffaloes.

\section{Dynamics of income structure across the land holding categories}

Table 3 presents the dynamics of income structure across the land holding categories. Income structure of small landholding farmers differs from the marginal farmers, nearly half ( 48.29 per cent) of their income was earned from crop production alone. However, over the decade (2002-03 to 2012-13), contribution of crop production in total income reduced drastically (from 57.14\% to $48.29 \%$ ), but absolute income increased 1.19 times over the same period. Other than crop production, small landholding farmers have been earning subsequent higher income from dairy farming i.e. 31.01 per cent, whereas, at country level its share is around 12 per cent only (Ranganathan, 2015). Income from dairy farming increased 1.67 times over the decade (2002-03 to 201213). Collectively income from crop production and dairy farming has been contributing nearly 79.30 per cent to the small land holding farmers income. In small landholding farmers income, off-farm business and wages and salaries income share was 13.65 and 7.05 per cent respectively. Income from both of these sources 
increased 1.75 times over the decade (2002-03 to 2012-13). Overall, this category of farmers realized 1.41 times increase in income in the same period. The contribution of crop production income in total household income was highest $(61.30 \%)$ in semi-medium landholding farmers. Crop production income share over the period (2002-03 to 2012-13) decreased from 68.20 to 61.30 per cent. Whereas, contribution of dairy farming income in total income remained stable (around 21\%) over the same period. In semi-medium landholding, farmers income contribution of dairy farming was less as in absolute amount as compared to small landholding farmers. In absolute terms, crop production income and dairy farming income increased relatively less i.e. 1.05 and 1.18 times respectively over the decade (2002-03 to 2012-13) as compared to small and marginal category of farmers. Both of these enterprises are contributing around 83 per cent in income of semi-medium farmers. Wages and salaries income share in this category of farmer was nearly 11 per cent, which was proportionally higher as compared to other categories of farmers except marginal farmers. Overall semi-medium farmers income increased 1.17 times, which was modest increase as compared to other categories of farmers over the decade (2002-03 to 2012-13). Medium landholding farmers realized over 98 per cent income from crop production and dairy farming, which is 87.66 and 10.77 per cent respectively. Crop production and dairy farming income increased 1.38 and 1.07 times over the decade (2002-03 to 201213). In the same period proportional contribution of income from crop production in total income increased in medium landholding farmers only. Overall, income of medium landholding farmers increased 1.21 times. Large landholding farmers' major source of income is crop production, which contributes 89.25 per cent in

Table 1 Growth of different female bovine species population and milk production across the districts (2000-01 to 2017-18)

\begin{tabular}{|c|c|c|c|c|c|c|c|c|}
\hline \multirow[t]{3}{*}{ Districts } & \multirow{3}{*}{$\frac{\text { Crossbred }}{\text { Population }}$} & \multirow{2}{*}{$\begin{array}{l}\text { Cow } \\
\text { Milk }\end{array}$} & \multicolumn{2}{|c|}{ Indigenous Cow } & \multicolumn{2}{|l|}{ Buffalo } & \multicolumn{2}{|l|}{ Bovine } \\
\hline & & & Population & Milk & Population & Milk & Population & Milk \\
\hline & & Production & & Production & & Production & & Production \\
\hline Gandhinagar & 14.31 & 14.33 & 0.76 & 3.32 & 2.53 & 4.22 & 3.75 & 6.27 \\
\hline Banaskantha & 25.19 & 25.02 & 4.52 & 5.61 & 5.09 & 5.95 & 6.62 & 8.92 \\
\hline Kachchh & 9.71 & 9.82 & 3.88 & 6.46 & 5.49 & 6.97 & 4.56 & 6.73 \\
\hline Mahesana & 12.13 & 11.58 & 1.36 & 2.33 & 0.66 & 1.39 & 2.15 & 3.70 \\
\hline Patan & 14.46 & 13.76 & 0.68 & 2.08 & 2.35 & 2.92 & 2.15 & 3.13 \\
\hline Sabarkantha & 16.91 & 18.66 & 1.00 & 2.02 & 1.56 & 3.08 & 3.38 & 6.51 \\
\hline North Gujarat & 17.13 & 17.42 & 2.76 & 4.27 & 2.87 & 3.87 & 4.11 & 6.25 \\
\hline Bharuch & 12.56 & 12.52 & 1.32 & 3.93 & -0.52 & 0.57 & 1.34 & 2.55 \\
\hline Narmada & 10.81 & 11.89 & 1.74 & 4.93 & 3.15 & 4.65 & 2.44 & 5.05 \\
\hline Surat & 14.37 & 14.98 & -5.09 & -3.19 & -1.19 & 0.46 & -0.59 & 2.35 \\
\hline Tapi & 8.82 & 10.68 & -0.69 & 2.84 & 0.76 & 2.93 & 0.37 & 5.82 \\
\hline Valsad & 11.54 & 11.84 & -2.23 & -0.87 & 1.28 & 2.19 & 1.93 & 5.32 \\
\hline Dang & 8.52 & 8.73 & -1.27 & 16.28 & 5.55 & 8.10 & 3.06 & 19.14 \\
\hline Navsari & 16.50 & 17.61 & -6.47 & -4.41 & -0.46 & 0.31 & 2.69 & 6.60 \\
\hline South & 14.46 & 16.78 & -1.25 & 0.93 & 1.32 & 2.63 & 2.23 & 5.64 \\
\hline \multicolumn{9}{|l|}{ Gujarat } \\
\hline Amreli & 10.47 & 11.66 & 2.91 & 4.85 & 2.37 & 4.47 & 2.67 & 4.75 \\
\hline Bhavnagar & 11.24 & 11.78 & 3.36 & 4.55 & 2.68 & 3.52 & 3.06 & 4.13 \\
\hline Jamnagar & 6.37 & 6.30 & 1.81 & 4.71 & 4.38 & 6.11 & 3.25 & 5.58 \\
\hline Junagadh & 17.12 & 19.17 & 2.85 & 5.29 & 2.27 & 4.47 & 2.68 & 5.09 \\
\hline Porbandar & 10.57 & 12.34 & 0.83 & 3.29 & 1.88 & 3.56 & 1.55 & 3.50 \\
\hline Rajkot & 11.12 & 11.36 & 2.00 & 3.96 & 3.52 & 5.04 & 3.04 & 5.00 \\
\hline Surendranagar & 25.26 & 25.05 & 4.16 & 6.70 & 5.87 & 7.29 & 5.02 & 7.10 \\
\hline Saurashtra & 12.34 & 12.99 & 2.75 & 4.89 & 3.22 & 4.84 & 3.13 & 5.07 \\
\hline \multicolumn{9}{|l|}{ Region } \\
\hline Kheda & 14.67 & 16.76 & 2.22 & 3.59 & 1.93 & 4.70 & 2.97 & 6.38 \\
\hline Anand & 9.73 & 12.40 & 1.10 & 3.84 & 1.22 & 3.35 & 2.15 & 5.17 \\
\hline Panchmahal & 27.53 & 28.74 & 3.70 & 6.72 & 3.81 & 5.72 & 4.53 & 7.52 \\
\hline Dahod & 10.38 & 12.45 & 0.95 & 6.65 & -0.07 & 3.71 & 0.42 & 4.85 \\
\hline Ahmedabad & 10.69 & 11.41 & 1.65 & 4.05 & 2.69 & 4.53 & 2.49 & 4.67 \\
\hline Vadodara & 10.53 & 11.13 & 1.91 & 4.29 & 1.78 & 3.30 & 2.08 & 4.03 \\
\hline Central & 13.42 & 15.28 & 1.90 & 4.85 & 1.98 & 4.25 & 2.52 & 5.52 \\
\hline Gujarat & 15.64 & 16.50 & 2.07 & 4.31 & 2.51 & 4.09 & 3.19 & 5.69 \\
\hline
\end{tabular}


total income. Other sources (dairy farming, off-farm business, wages and salaries) of income have lower (11\%) contribution in farmers income. Overall, income of large landholding farmers increased 2.42 times over the decade (2002-03 to 2012-13) which is the highest increase realized by them as compared to all other categories of farmers. Overall farmers realized highest income from crop production activity, which contributes 48.12 per cent in total income. The share of income from crop production in total income decreased drastically from 55.84 to 48.12 per cent. After this the major source of income is dairy farming activity which contributes 28.20 per cent to farmers' income. The share of dairy farming activity increased from 24.32 to 28.20 per cent. Crop production and dairy farming together contributed 76.32 per cent in farmers' income (2012-13), which changed marginally over the decade (2002-03 to 2012-13), but proportional income share of dairy farming increased drastically and crop production income share decreased at the same time. Income from crop production increased marginally only 1.04 times, whereas income from dairy farming has increased 1.40 times over the decade (2002-03 to 2012-13). This shows that among the different income activities dairy farming registered highest income increase as compared to other household income activities. Wages and salaries share in total farmer income is 15.76 per cent in the year 2012-13. The wages and salaries share has increased drastically over the decade

Table 2 Decomposition of yield and population effects of livestock to growth of milk production

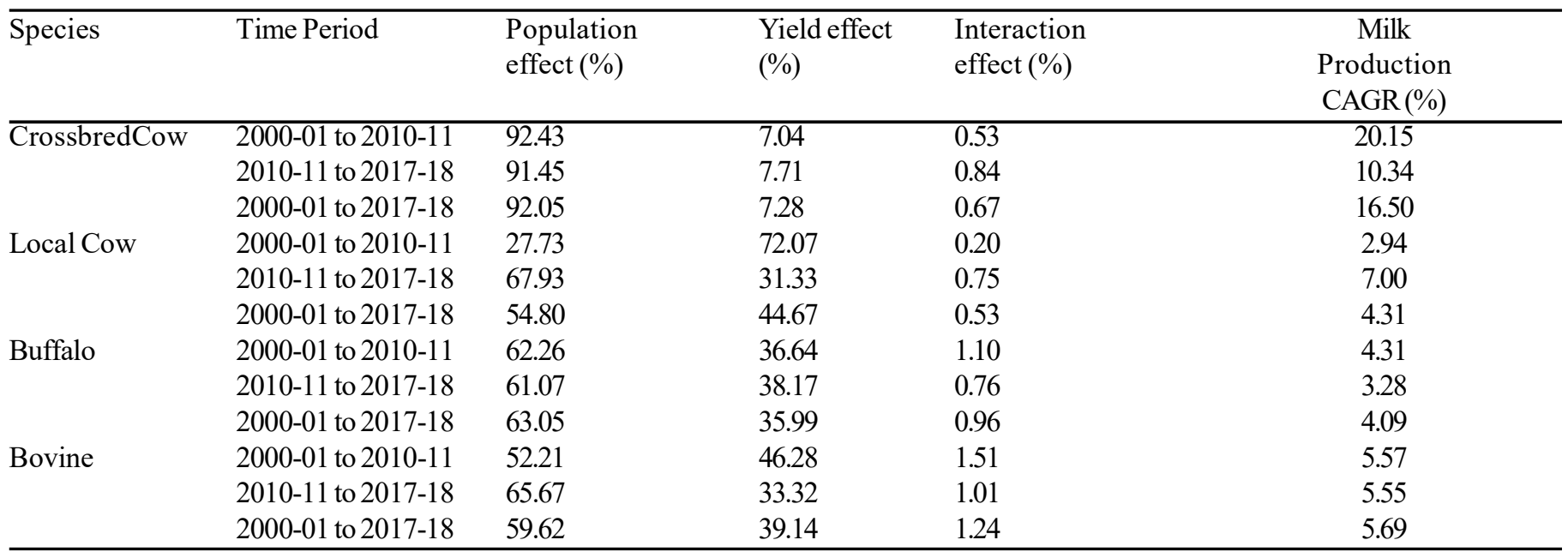

Table 3 Structural Changes in Farmers' Income (at constant price 2012-13) from Different Sources in Gujarat (2002-03 to 2012-13)

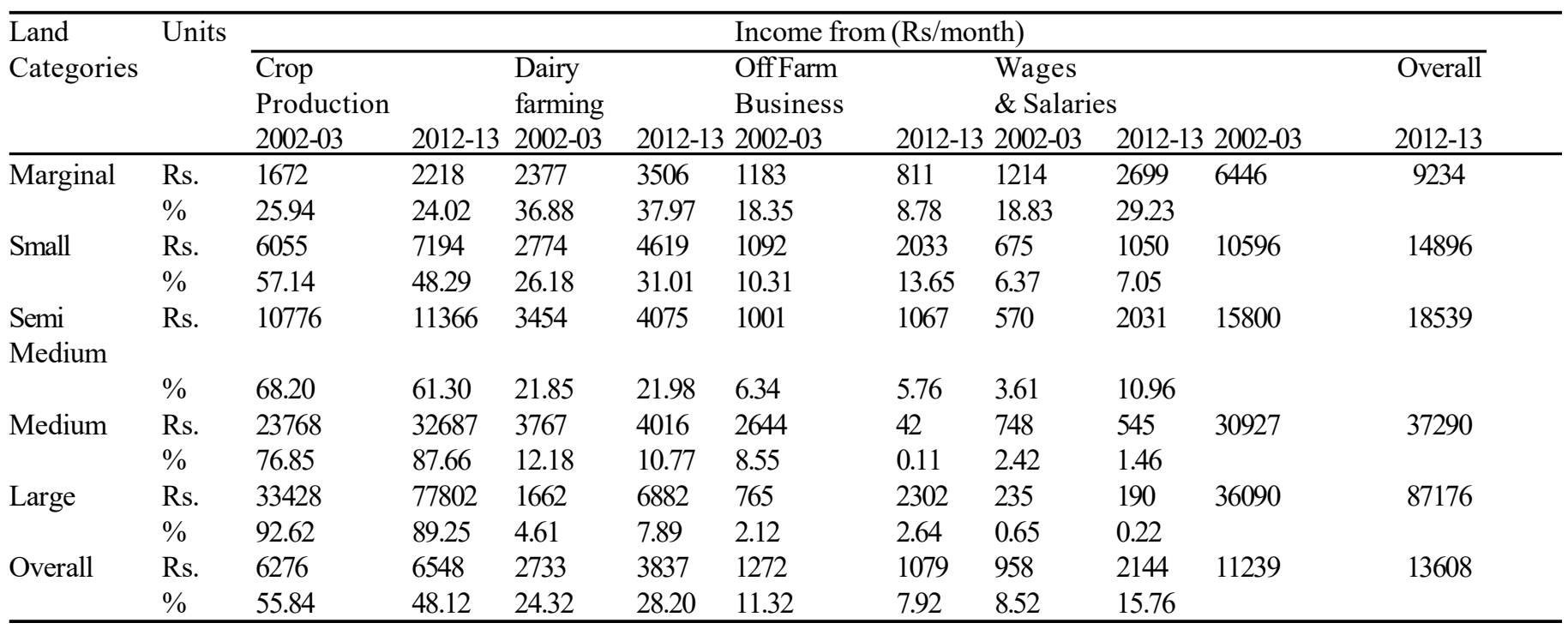

Source: The researchers estimates based on $59^{\text {th }}$ (visit-1) and $70^{\text {th }}$ (visit-1) rounds of NSSO, MOSPI, New Delhi.

Note: Real income is calculated by using the CPI-AL (General) series of base year 1986-87=100. Real income is at 2013 price level. Marginal: $\leq 1.00$ ha., Small: 1.01 to 2.00 ha., Semi-Medium : 2.01 to 4.00 ha., Medium : 4.01 to 10.00 ha. and

Large : $\geq 10.01$ ha. 
(2002-03 to 2012-13) from 8.52 to 15.76 per cent in farmers' income. This also shows importance of it in farmer's livelihood activity. Overall farmers' income increased 1.21 times over the 2002-03 to 2012-13.

Income dynamics shows that marginal landholding farmers income is 10 times lower as compared to large farmers, even 1.47 times lower than the average income of all farmers in the year 2012-13. The decadal trend shows that the marginal landholding farmers income were 5.60 times as compared to large farmers in the year 2002-03. Even large landholding farmers income increased (2.42 times) at faster pace as compared to marginal landholding farmers (1.41 times) over the decade (2002-03 to 2012-13). This trend shows that over the period, marginal farmers income increased but inequality in income distribution is also important. This poses the question whether income growth is inclusive or exclusive. At the same time, it is important to see what are the sources of inequality. It is also equally important to look at the pattern of income source wise inequalities.

\section{Structural changes in source wise income inequality}

Table 4 presents the sourcewise income share and its correlation with total income and their contribution to the overall income inequality. The Gini inequality of total household income was estimated at 0.7012 indicating that income distribution among different household levels was almost unequal. The analysis further established that in the total household income, the share of crop income was highest (48.12\%) followed by dairy farming $(28.20 \%)$, wages \& salaries $(15.76 \%)$ and off-farm business $(7.92 \%)$ income. It was observed that 1 per cent incremental increase in crop income will trigger total income inequality by 0.75 per cent with a caveat that other things are unchanged. The results of the study were in agreement with Singh \& Datta (2013) findings in

Table 4 Structural Changes in Sources of Income Inequality (2012-13)

\begin{tabular}{lllc}
\hline Income Sources & Income share & $\begin{array}{l}\text { Correlation with } \\
\text { sources of total } \\
\text { income }\end{array}$ & Marginal effect \\
\hline Crop Production & 0.4812 & 0.9146 & 0.0075 \\
Dairy farming & 0.2820 & 0.8705 & -0.0048 \\
Off Farm Business & 0.0792 & 0.8338 & 0.0093 \\
Wages \& Salaries & 0.1576 & 0.7601 & -0.0120 \\
\hline
\end{tabular}

Source: The researcher estimates based on $70^{\text {th }}$ (visit-1) rounds of NSSO, MOSPI, New Delhi

Table 5 Different sources of income by the dairy farmers (DF) and non-dairy farmers (NDF) for their livelihood activities during 2012 13

\begin{tabular}{|c|c|c|c|c|c|c|c|}
\hline \multirow[t]{2}{*}{$\begin{array}{l}\text { Land } \\
\text { Categories }\end{array}$} & \multirow[t]{2}{*}{$\begin{array}{l}\text { Type } \\
\text { of farmers }\end{array}$} & \multirow[t]{2}{*}{$\begin{array}{l}\text { Landholding } \\
\text { size (ha) }\end{array}$} & \multicolumn{4}{|c|}{$\begin{array}{l}\text { Income } \\
\text { from }(\%)\end{array}$} & \multirow[t]{2}{*}{$\begin{array}{c}\text { Overall } \\
\text { (Rs/month) }\end{array}$} \\
\hline & & & $\begin{array}{l}\text { Crop } \\
\text { Production }\end{array}$ & $\begin{array}{l}\text { Dairy } \\
\text { farming }\end{array}$ & $\begin{array}{l}\text { Off } \\
\text { Farm } \\
\text { Business }\end{array}$ & $\begin{array}{l}\text { Wages } \\
\& \text { Salaries }\end{array}$ & \\
\hline \multirow[t]{2}{*}{ Marginal } & $\overline{\mathrm{DF}}$ & 0.36 & 21.60 & 42.19 & 8.59 & 27.62 & 9862 \\
\hline & $\mathrm{NDF}$ & 0.50 & 45.87 & 0.00 & 10.08 & 44.05 & 5793 \\
\hline \multirow{2}{*}{$\begin{array}{l}\text { Semi } \\
\text { Medium }\end{array}$} & $\mathrm{DF}$ & 2.72 & 59.77 & 27.30 & 3.66 & 9.28 & 19371 \\
\hline & $\mathrm{NDF}$ & 2.76 & 67.88 & 0.00 & 14.48 & 17.64 & 16163 \\
\hline \multirow[t]{2}{*}{ Medium } & $\mathrm{DF}$ & 6.20 & 86.15 & 12.20 & 0.13 & 1.52 & 40374 \\
\hline & $\mathrm{NDF}$ & 4.59 & 97.05 & 0.00 & 1.72 & 1.23 & 26199 \\
\hline & $\mathrm{NDF}$ & 1.38 & 58.92 & 0.00 & 22.32 & 18.76 & 10560 \\
\hline Overall & $\mathrm{DF}+\mathrm{NDF}$ & 1.28 & 48.11 & 28.16 & 7.97 & 15.75 & 13624 \\
\hline
\end{tabular}

Note: Marginal: d" 1.00 ha., Small: 1.01 to 2.00 ha., Semi-Medium : 2.01 to 4.00 ha., Medium : 4.01 to10.00 ha. and Large : e"10.01 ha. 
Table 6 Partial productivity parameters (at constant price, 2015-16) of organised dairy industry in Gujarat

\begin{tabular}{ll}
\hline Parameters \\
Ex-factory value of output per factory (Rs in Millions) \\
Ex-factory value of output per fixed capital (Rs) \\
Ex-factory value of output per labour (Rs in Millions) \\
Fixed capital (Rs in Millions) \\
\hline Table 7 Total factor productivity (TFP) of organised dairy \\
industry in Gujarat \\
\hline Year & TFP \\
\hline $2001-02$ & 1.082 \\
$2002-03$ & 1.188 \\
$2003-04$ & 0.891 \\
$2004-05$ & 1.018 \\
$2005-06$ & 1.181 \\
$2006-07$ & 1.021 \\
$2007-08$ & 0.963 \\
$2008-09$ & 0.999 \\
$2009-10$ & 1.213 \\
$2010-11$ & 1.108 \\
$2011-12$ & 0.884 \\
$2012-13$ & 1.001 \\
$2013-14$ & 1.090 \\
$2014-15$ & 1.041 \\
$2015-16$ & 1.002 \\
Mean & 1.045 \\
\hline CAGR (\%) & -0.31 \\
\hline
\end{tabular}

India that income inequality among the farm households reduced by income realized from non-farm and livestock activities. However, income from crop production increases the income inequality among the households. On the other hand, the income from dairy farming $(-0.48 \%)$ and wages \& salaries $(-1.20 \%)$ has an equalising effect on the distribution of total income for farm households, which otherwise corroborates the hypothesis of relative income equalising effect through dairying and wages $\&$ salaries compared to distribution of incomes through crop and off farm business. Though the income share from dairy sector was around quarter of total income but its contribution towards rural livelihood was more secured than other sources. This reemphasises the importance of dairying in farming system for its doubly beneficial social impact in improving incomes and reducing income inequality. It also confirms that growth through inclusive dairying does not worsen income distribution, but helps in reducing absolute poverty. For prioritising rural livelihood, the incorporation of dairy activity within different income sources is needed to achieve higher social benefits and distributive justice.

\section{Dairy Income as a source of rural livelihood}

The different sources of income by the dairy farmers (DF) and non-dairy farmers (NDF) for their livelihood activities during the year 2012-13 is shown in Table 5. The income of farmers from dairy farming varies widely across the different land categories

$\begin{array}{llc}2000-01 & 2010-11 & 2015-16 \\ 389.60 & 925.57 & 1638.07 \\ 15.21 & 11.38 & 5.15 \\ 4.81 & 7.18 & 5.54 \\ 36239 & 134138 & 668682\end{array}$

e.g., in marginal category contribution is around Rs. 4161 per month $(42.19 \%)$ while in the case of large landholding category it is Rs. 7663 per month (6.40\%). Across the landholding categories, land size within the land categories among the dairy farmers and non-dairy farmers is not varies much in lower size of landholding categories. Mainly income from dairy farming creates sizable income differences within and between landholding categories like income of dairy and non-dairy farmers of marginal landholding varies from Rs. 9862/ month to Rs. 5793/month i.e 42.19 per cent difference is in respective incomes. Similarly, income of small landholding dairy and non-dairy farmers varies from Rs. 16209/ month to Rs. $12007 /$ month respectively. The difference due to dairy income alone is 39.70 per cent. Overall income of dairy and non-dairy farmers is Rs. 14350/month and Rs. 10560/month respectively. This shows income difference among the farmers is 33.08 per cent due to dairy enterprise alone. The contribution of dairy farming to income decreased over the land categories as the size of land increased. The income of the dairy farmers is higher compared to non-dairy farmers across all the categories and in case of overall farmers also. Therefore, dairy is an important component that will help in doubling farmers income in different magnitudes across the landholding categories. Among the marginalized farmers (marginal and small landholder) dairy enterprise can increase the farmers income around 39.70 to 42.19 per cent. In comparison to marginal farmers, the large farmers earned 12.14 times higher income, but income from dairying sustained the livelihood of marginal farmers.

\section{Organized dairy industry for sustaining dairy farming}

The partial productivity parameters of organised dairy sector in Gujarat is presented in Table 6. During the period 2000-01 to 2015-16, the ex-factory value of output per factory was increased 4.20 times while the ex-factory value of output per labour has remained stagnant over the same period. In the same period, the fixed capital investment in the organised dairy industry has increased 18.45 times. But, the ex-factory value of output per rupee of fixed capital decreased from Rs. 15.21 to Rs. 5.15 during 2000-01 to 2015-16. This indicates that the excess investment in dairy industry has happened over the period which has not resulted in increase in value of output from the industry. This trend shows that it is possible that without addition in capital investment organized dairy industry can sustain in near future condition is to use full capacity.

Table 7 shows the total factor productivity of organised dairy industry in Gujarat during the period 2000-01 to 2015-16. Total 
factor productivity was higher in eleven years except years 200304, 2007-08, 2008-09 and 2011-12. Overall TFP growth over the study period was registered -0.03 per cent. This shows that in organized dairy industry over the long period input - output relationship has not changed much may be because of higher fixed capital investment and lower milk collection with respect to capacity of dairy plant (Table 6).

\section{Conclusions}

The study has brought to the fore that overall milk production in Gujarat increased by the combined effect of population (59.62\%) and yield effects $(39.14 \%)$ where population effect led milk production is more in cross bred cow $(92.05 \%)$ and yield effect that led milk production is mainly observed in indigenous cow $(44.67 \%)$ and buffalo $(35.99 \%)$. For productivity led growth instead of population led growth in milk production, there is an absolute need to promote the indigenous cow and buffalo. The income from dairy farming increased higher (1.40 times over the decade) as compared to other income activities (crop production, off-farm business, wages and salaries) and has an equalising effect on the distribution of farm income. Contribution of dairy income in farm income is higher especially in the case of marginal (37.97\%) and small (31.01\%) land owning farm households. At the same time income of dairy farmers is higher compared to non dairy farmers. Therefore, government should give more focus on promotion of dairy farming in the programmes designated for enhancing farmer's income and to reduce income inequalities. Ex-factory value of output per organized dairy processing factory was increased 4.20 times while tfixed capital investment increased 18.45 times over the period (2000-01 to 2015-16). This indicates that the excess investment in dairy industry might have happened over the period which has perhaps not resulted in increase in value of output from the industry. This trend shows that it is possible that without addition in capital investment organized dairy industry can sustain in near future the condition is to use full capacity, this way dairy industry and farmers remain in winwin situation.

\section{References}

CSO (2008) Statewise estimates of value of output from agriculture and allied activities with new base-year 1999-2000 (1999-2000 to 200506). Ministry of Statistics and Programme Implementation, Government of India, New Delhi

CSO (2016-17) National Accounts Statistics. Ministry of Statistics and Programme Implementation, Government of India, New Delhi

CSO (2018). Statewise and item-wise estimates of value of output from agriculture and allied

Ghose A, Biswas PR (2012) Inter industrial variation of productivity growth in Indian manufacturing sector: Evidence from a nonparametric approach. J Industrial Stat 1: 57-81

Kumar A, Kumar S, Singh DK, Shivjee (2011) Rural employment diversification in India: trends, determinants and implications on poverty. Agric Econ Res Rev 24 :361-372

Kumar A, Mishra AK, Parappurathu S, Jha GK (2018) Farmers' choice of milk-marketing channels in India. Economic \& Political Weekly 80(51): 58-67

Kumar A, Parappurathu S, Joshi PK (2013) Structural Transformation in Dairy Sector of India. Agric Econ Res Rev 26: 209-219

Kumar A, Singh DK (2008). Livestock production system in India: An appraisal across agro-ecological regions. Indian J Agric Econ 63: 577-597

Mandal S, Datta KK, Lama TD (2010) Economic evolution of farming system research in NEH region: some issues. Indian J Agric Econ 65: 118-134

National Dairy Development Board (2018) Milk production by states. Anand, Gujarat

Ranganathan T (2015). Farmers' Income in India: Evidence from Secondary Data. Research Report. Agricultural Economics Research Unit, Institute of Economic Growth, New Delhi.

sectors (2011-12 to 2015-16). Ministry of Statistics and Programme Implementation, Government of India, New Delhi

Singh SR, Datta KK (2010) Understanding value addition in Indian dairy sector: Some perspectives. Agric Econ Res Rev23: 487-493

Singh SR, Datta KK (2013) Future of Smallholders in the Indian Dairy Sector - Some Anecdotal Evidence. Indian J Agric Econ 68: 182194 